\title{
PROFIL USAHA RUMAH KOPI MONOCAFE DI KELURAHAN WENANG SELATAN KOTA MANADO
}

\author{
Renovaldo Imanuel Apituley \\ Benny Adrian Berthy Sagay \\ Jean Fanny Juanita Timban
}

\begin{tabular}{ll}
\hline Naskah diterima melalui Website Jurnal Ilmiah agrisosioekonomi@ unsrat.ac.id & $:$ Jumat, 12 Juli 2019 \\
Disetujui diterbitkan & $:$ Kamis, 25 Juli 2019 \\
\hline
\end{tabular}

\begin{abstract}
This study aims to determine the business profile of Manado Monocafe Coffee House and to find out how much profit from the Monocafe Coffee House business that sells coffee and food drinks. This research was conducted at Monocafe Coffee House in Wenang Selatan Village, Manado City. Data retrieval is done by direct interview with the coffee house owner (one respondent). Data collected is the characteristics of business actors, financial aspects, management aspects, technical and production aspects, marketing aspects, and profits. Secondary data was obtained from the Monocafe Coffee House business profile, local book store, internet through google searching to obtain journal articles and thesis related to the research topic about the business profile of Monocafe Coffee House. Data analysis using descriptive analysis and profit analysis. The results showed that the Monocafe Coffee House business was a small business. Started operating since 2016 by using its own capital. The amount of coffee raw material used in one month (in August 2018) is $6 \mathrm{Kg}$ producing 1,156 drinks and 662 food items. The advantage obtained with the $R / C>1$ ratio is 1.40. This means that in August 2018 the Monocafe Coffee House business has benefited so that this business is worthy of continuing. ${ }^{-{ }^{-e p e r m} *}$
\end{abstract}

Keywords : business profile, coffee, benefits.

\begin{abstract}
ABSTRAK
Penelitian ini bertujuan untuk mengetahui profil usaha Rumah Kopi Monocafe Manado dan untuk mengetahui berapa besar keuntungan dari usaha Rumah Kopi Monocafe yang menjual minuman kopi dan makanan. Penelitian ini dilakukan di Rumah Kopi Monocafe di Kelurahan Wenang Selatan Kota Manado. Pengambilan data dilakukan dengan cara wawancara lansung dengan pemilik rumah kopi (satu responden). Data yang dikumpulkan adalah karakteristik pelaku usaha, aspek keuangan, aspek manajemen, aspek teknis dan produksi, aspek pemasaran, dan keuntungan. Data sekunder diperoleh dari profil usaha Rumah Kopi Monocafe, toko buku lokal, internet melalui google searching untuk mendapatkan artikel jurnal dan skripsi yang berkaitan dengan topik penelitian tentang profil usaha Rumah Kopi Monocafe. Analisis data menggunakan analisis deskriptif dan analisis keuntungan. Hasil penelitian menunjukkan bahwa usaha Rumah Kopi Monocafe merupakan usaha kecil. Mulai beroperasi sejak 2016 dengan menggunakan modal sendiri. Jumlah bahan baku kopi yang digunakan dalam satu bulan (bulan Agustus 2018) adalah $6 \mathrm{Kg}$ menghasilkan 1.156 gelas minuman dan 662 porsi makanan. Keuntungan yang diperoleh dengan rasio R/C > 1 yaitu 1,40. Artinya pada bulan Agustus 2018 usaha Rumah Kopi Monocafe mengalami keuntungan sehingga usaha ini layak untuk terus diusahakan. ${ }^{-{ }^{*} \text { eprm* }}$
\end{abstract}

Kata kunci : profil usaha, kopi, keuntungan. 


\section{PENDAHULUAN}

\section{Latar Belakang}

Tumbuhan kopi diperkirakan berasal dari hutan-hutan tropis dikawasan Afrika. Kopi Arabika berasal dari kawasan pegunungan tinggi di Barat Ethiopia maupun di kawasan utara Kenya, kopi Robusta di Ivory Coast dan Republik Afrika Tengah. Hal ini membuktikan bahwa tumbuhan kopi mudah beradaptasi dengan lingkungan tumbuhnya (Siswoputranto, 1992).

Kopi juga merupakan salah satu hasil komoditi perkebunan yang memiliki nilai ekonomis yang cukup tinggi di antara tanaman perkebunan lainnya dan berperan penting sebagai sumber devisa Negara. Kopi tidak hanya berperan penting sebagai sumber devisa melainkan juga merupakan sumber penghasilan bagi tidak kurang dari satu setengah juta jiwa petani kopi di Indonesia (Rahardjo, 2012).

Di Indonesia saat ini tanaman kopi menempati urutan ketiga terbesar di dunia dari hasil produksi setelah Brazil dan Kolombia (Dirjen Perkebunan, 2014). Tanpa membedakan jenisnya, produksi kopi dunia dalam enam tahun terakhir (2004-2009) mengalami pertumbuhan yang positif yaitu 5,5 persen per tahun. Pertumbuhan tersebut terjadi karena sebagian besar Negara-negara produsen kopi mengalami pertumbuhan yang positif.

Kopi di Indonesia memiliki sejarah yang panjang dan memiliki peranan penting bagi pertumbuhan perekonomian masyarakat di Indonesia. Indonesia memiliki letak geografis yang sangat cocok difungsikan sebagai lahan perkebunan kopi. Letak Indonesia sangat ideal bagi iklim mikro untuk pertumbuhan dan produksi kopi (Widiyanto, 2012).

Kopi juga bisa dibuat menjadi minuman dengan cara hasil seduhan biji kopi yang telah disangrai dan dihaluskan menjadi bubuk diseduh dengan air panas maupun dingin. Kopi merupakan salah satu komoditas di dunia yang dibudidayakan lebih dari 50 negara. Dua varietas pohon kopi yang dikenal secara umum yaitu Kopi Robusta (Coffeacanephora) dan Kopi Arabika (Coffea arabica) (S, 2013).

Berbicara tentang profil usaha adalah sebuah laporan yang memberikan gambaran tentang sejarah, status usaha tani, dan tujuan masa depan sebuah bisnis. Profil usaha dapat mendiskusikan rencana untuk ekspansi masa depan dalam hal lokasi, produk atau jasa baru yang diantisipasi akan ditawarkan dalam waktu dekat, atau rencana untuk merestrukturisasi operasi sebagai bagian dari strategi untuk memastikan keberhasilan lanjutan dari bisnis.

Tujuan dibuatnya profil usaha adalah untuk memberikan informasi selengkapnya tentang aspek kekuatan usaha dan memberikan informasi kepada masyarakat agar mereka dapat mempertimbangkan untuk menggunakan produk atau jasa yang ditawarkan oleh suatu usaha (Syarizal, 2015).

Kondisi Indonesia yang semakin berkembang dalam era globalisasi ini, mengakibatkan perekonomian yang semakin hari semakin kemerosotan, sedangkan peningkatan taraf hidup sangat diperlukan oleh masyarakat Indonesia. Hal ini membuat masyarakat Indonesia lebih kreatif dan inovatif dalam menciptakan lapangan pekerjaan atau membuka usaha.

Indonesia sebagai Negara penghasil produksi kopi terbesar ketiga di Dunia setelah Brazil dan Kolombia banyak masyarakat yang menggunakan kopi sebagai bahan baku untuk menciptakan suatu peluang usaha contohnya seperti rumah kopi yang sudah mulai populer di berbagai wilayah di Indonesia (Stanly E, 2015).

Usaha rumah kopi di Kota Manado sudah cukup lama diusahakan oleh sejumlah kalangan masyarakat baik untuk dikonsumsi masyarakat sekitar maupun dikonsumsi sendiri oleh masingmasing orang. Kopi pada awalnya hanya dikonsumsi oleh sebagian orang pada waktu dan tempat tertentu, namun saat ini kopi sudah menjadi minuman siap saji yang bisa diperoleh di berbagai tempat.

Rumah kopi sudah banyak tersebar di berbagai tempat di Kota Manado, salah satu usaha rumah kopi adalah rumah kopi Monocafe yang terletak di jalan Boulevard Manado. Usaha rumah kopi Monocafe adalah usaha kecil yang sudah ada dari tahun 2016 sampai sekarang. Selain harganya yang sangat terjangkau, rasa kopinya juga enak, apalagi tempat usahanya yang sangat strategis karena berada tidak jauh dari pinggir jalan utama Boulevard Manado.

\section{Industri Kecil dan Menengah}

Ariadi dkk (2011), Berdasarkan jumlah teanga kerja indutri terbagi menjadi beberapa kategori yaitu : 
a. Industri besar dengan pekerja 100 orang atau lebih

b. Industri sedang dengan pekerja 20-99 orang

c. Industri kecil dengan pekerja 5-19 orang

d. Industri rumah tangga dengan pekerja kurang dari 5 orang.

\section{Rumah Kopi}

Rumah kopi atau diesebut warung kopi adalah konsep warung khusus kopi yang didesain untuk meminum kopi dalam keadaan panas dan dingin yang dibuat dari bahan-bahan kopi asli dari biji kopi terpilih dan beragam. Warung kopi menawarkan pengalaman (experience) minum kopi dengan atmosfir kedai kopi yang nyaman untuk menikmati minum kopi menjadi sesuatu yang menyenangkan.Warung kopi menawarkan pelanggannya berbagai macam kopi berkualitas seperti Cappuccino, Mocca, vanilla. Minuman tersebut disajikan oleh "Barista" orang yang terlatih dengan keahliannya dalam membuat minuman kopi (Salim, 2016).

\section{Faktor Pendukung Pengembangan Industri Hasil Pertanian}

\section{Bahan Baku}

Bahan baku merupakan salah satu factor input yang sangat diperlukan karena tanpa adanya bahan baku proses produksi tidak dapat berjalan. Industri pengolahan hasil pertanian adalah industri yang bahan bakunya berasal dari hasil-hasil pertanian yang membutuhkan bahan baku dalam jumlah yang banyak, kualitas, dan waktu yang tetap terus menerus (Assuari, 1999 dalam skripsi Kurniawan, 2005).

\section{Tenaga Kerja}

Tenaga kerja adalah satu factor penting dalam membangun sebuah usaha. Bagi usaha kecil yang baru mulai berjalan merekrut karyawan mungkin belum begitu penting. Namun, kalau usaha sudah berkembang merekrut tenaga kerja merupakan hal penting yang harus dilakukan. (Oskar dkk, 2010).

\section{Modal}

Pengertian ekonomi, modal adalah barang atau uang yang bersama-sama dengan faktor produksi yang lain menghasilkan suatu produk baru. (Kurniawan, 2005).

\section{Pengolahan (Manajemen)}

Manajemen merupakan sebuah subjek yang mempersoalkan usaha penetapan tujuan. Sebagai alat manajemen bukan saja ditujukan untuk mengidentifikasi, menganalisa dan menetapkan tujuan-tujuan yang harus dicapai, tetapi juga untuk mengkombinasikan secara efektif bakat dan keahlian orang-orang dan mendaya gunakan sumber-sumber material secara efesien (Ariadi dkk, 2011).

\section{Teknologi}

Teknologi adalah suatu metode atau teknik untuk mengubah barang agar memperoleh nilai yang lebih tinggi dan diminati konsumen. (Soekartawi, 2001 dalam skripsi Kurniawan, 2005).

\section{Pemasaran}

Oskar dkk (2010), pemasaran adalah suatu proses manajerial yang membuat individu atau kelompok mendapatkan apa yang mereka butuhkan dan inginkan dengan menciptakan, menawarkan, dan mempertukarkan produk yang bernilai kepada pihak lain atau segala kegiatan yang menyangkut penyampaian produk atau jasa mulai dari produsen sampai konsumen. Dalam Skripsi Kurniawan (2005), untuk menciptakan dan memelihara pasar produk, kegiatan pemasaran dapat diklasifikasikan dalam bauran pemasaran sebagai berikut:

1. Produk

Produk merupakan hasil pengolahan dari suatu barang yang dapat memberikan nilai tambah dari barang tersebut serta dapat memuaskan kebutuhan konsumen.

2. Harga

Harga merupakan hasil kesepakatan antara pembeli dan penjual dalam menilai suatu produk yang berupa barang dan jasa.

3. Tempat

Menyangkut lokasi penjualan suatu produk untuk mencapai sasaran.

4. Promosi

Promosi merupakan kegiatan yang dilakukan berupa penyebaran informasi tentang produk yang dihasilkan yang bertujuan untuk meningkatkan penjualan produk.

\section{Konsep Biaya}

Biaya adalah bagian dari harga pokok yang dikorbankan dalam suatu usaha untuk memperoleh penghasilan (Mulyadi, 1999) dengan demikian biaya merupakan pengorbanan ekonomis yang diukur dengan nilai uang untuk memperoleh barang atau jasa. Ada dua komponen biaya yaitu: 
Biaya adalah pengorbanan sumber ekonomis yang diukur dalam satuan uang, yang terjadi atau yang kemungkinan akan terjadi untuk mencapai tujuan tertentu, dalam arti sebagai pengorbanan sunber ekonomi, untuk memperoleh aktiva yang disebut dengan istilah harga pokok. Dengan kata lain biaya adalah bagian dari harga pokok yang dikorbankan dalam suatu usaha untuk memperoleh penghasilan (Mulyadi, 1999) dengan demikian biaya merupakan pengorbanan ekonomis yang diukur dengan nilai uang untuk memperoleh barang atau jasa.

Analisis biaya dan pendapatan sangatlah penting untuk mengetahui tingkat kehidupan dan keberhasilan suatu usaha. Mubyarto (2004) menyatakan bahwa biaya adalah semua pengeluaran yang dinyatakan dengan uang, digunakan untuk keperluan menghasilkan suatu periode produksi. Ada dua komponen biaya yaitu:

\section{a. Biaya tetap}

Biaya tetap adalah biaya yang sifatnya tidak dipengaruhi oleh produksi, seperti sewa tanah, bunga pinjaman, dan merupakan kewajiban yang harus dibayar oleh suatu usaha per satuan waktu tertentu, untuk keperluan pembayaran semua input tetap dan besarnya tidak tergantung dari jumlah produk yang dihasilkan.

\section{b. Biaya variabel}

Biaya variabel adalah kewajiban yang harus dibayar oleh suatu usaha pada waktu tertentu, untuk pembayaran semua input variabel yang digunakan dalam proses produksi dan sifatnya sesuai besarnya biaya produksi.

\section{Konsep Penerimaan}

Penerimaan diartikan sebagai target penciptaan berdasarkan selera pasar. Penerimaan berasal dari hasil penjualan produk baik berupa barang dan jasa usaha. Menurut Soekartawi (2003), penerimaan adalah jumlah semua produksi yang dihasilkan dalam suatu kegiatan usaha dikalikan dengan harga yang berlaku dipasaran secara matematis dirumuskan sebagai berikut:

Dimana,

$$
\mathrm{R}=\mathrm{P} \times \mathrm{Q}
$$

$$
\begin{aligned}
& \mathrm{R}=\text { Penerimaan } \\
& \mathrm{P}=\text { Harga pokok } \\
& \mathrm{Q}=\text { Jumlah produk }
\end{aligned}
$$

\section{Konsep Keuntungan}

Dengan demikian, sebagai ukuran keberhasilan dalam menghasilkan keuntungan dapat dilihat dari tinggi rendahnya profit margin serta tingkat pengembaliannya.

Adapun unsur-unsur yang dikaji dalam analisis keuntungan yaitu:

a. Biaya

b. Penerimaan

Keuntungan adalah selisih antara penerimaan dengan semua biaya. Keuntungan maksismum dapat ditingkatkan dengan cara meminimumkan biaya untuk penerimaan yang tepat atau meningkatkan penerimaan dengan biaya (Soekartawi, 2000), yaitu :

Dimana,

$$
\boldsymbol{\pi}=\mathbf{T R}-\mathbf{T C}
$$

$$
\begin{array}{ll}
\boldsymbol{\pi} & =\text { Keuntungan } \\
\mathrm{TR} & =\text { Total Penerimaan (Total Revenue) } \\
\mathrm{TC} & =\text { Total Biaya (Total Cost) }
\end{array}
$$

\section{Penelitian Terdahulu}

Penelitian yang dilakukan oleh Ketak Yuli Ambara, I Nyoman Gede Ustriyana dan I ketut Rantau (2017) yang berjudul Profil Usaha Industri Kecil Tahu dan Tempe di Kecamatan Denpasar Barat, Kota Denpasar. Masalah dari penelitian ini adalah bagaimana profil usaha, pendapatan dan saluran pemasaran tahu dan tempe di Kecamatan Denpasar Barat Kota Denpasar. Sedangkan tujuan penelitian ini untuk mengetahui profil usaha, besarnya pendapatan, dan saluran pemasaran usaha tersebut.

Analisis data yang digunakan adalah analisis data secara deskriptif yaitu data yang diperoleh kemudian diolah, disusun, dan disajikan dalam bentuk tabel atau bagan yang sesuai.

Hasil dari penelitian ini adalah industry tahu dan tempe merupakan industri perorangan dengan modal yang digunakan adalah modal sendiri. Industri Makmur Jaya dalam memproduksi tahu dan tempe sebanyak 3.600 tahu, 1.000 tempe. Pendapatan yang diperoleh oleh Makmur Jaya dari usaha tahu dan tempe sebesar Rp.39.237.917 per bulan. Saluran pemasaran Makmur Jaya menjual produknya ke pasar tradisional dan sistem pembayaran tunai.

\section{Perumusan Masalah}

Rumusan dalam penelitian ini adalah bagaimana profil usaha Rumah Kopi Monocafe di Kelurahan Wenang Selatan Kota Manado. 


\section{Tujuan Penelitian}

Penelitian ini bertujuan untuk mengetahui profil usaha dari Rumah Kopi Monocafe di Kelurahan Wenang Selatan Kota Manado serta keuntungannya.

\begin{abstract}
Manfaat Penelitian
Dapat memeberikan gambaran mengenai profil usaha Rumah Kopi Monocafe maupun kesempatan bagi penerapan teori dan konsep tentang bisnis atau usaha di bidang agribisnis. Selain itu penelitian ini berguna bagi pelaku usaha sebagai informasi dalam mengelola dan meningkatkan keuntungan dalam usahanya.
\end{abstract}

\section{Konsep Profil Perusahaan}

Profil Perusahaan adalah gambaran umum tentang sebuah perusahaan menyangkut sejarah perusahaan, jenis perusahaan, struktur organisasi perusahaan, sistem permodalan, dan alamat perusahaan. Profil perusahaan ini berguna untuk beberapa hal seperti pengajuan peminjaman modal ke bank, untuk diperkenalkan ke public, dan sebagainya (Profil Perusahaan Contoh dan Pengertian, 2012).

\section{METODE PENELITIAN}

\section{Waktu dan Tempat Penelitian}

Penelitian ini berlangsung dari bulan Agustus sampai dengan bulan Oktober 2018 di Monocafe Manado yang dimulai pada persiapan, pengambilan data, sampai penyusunan laporan.

\section{Metode Pengambilan Data}

Pengambilan data pada penelitian ini adalah menggunakan data primer dan sekunder. Data primer diperoleh melalui metode wawancara dengan menggunakan daftar pertanyaan (kuesioner) kepada pemilik usaha, Sedangkan data sekunder diperoleh dari sumber lainnya seperti buku, jurnal dan skripsi. Penelitian ini bersifat studi kasus.

\section{Konsep Pengukuran Variabel \\ Variabel yang dihitung dalam profil usama rumah kopi Monocafe sebagai berikut :}

a. Karakteristik pelaku usaha: Umur (tahun), Jenis kelamin (laki-laki/perempuan), Jumlah anggota keluarga yang menjadi tanggungan (orang), Pendidikan.

b. Aspek keuangan: Modal, sumber modal, Harga jual produk, Jumlah biaya dalam pengadaan bahan baku. c. Aspek manajemen: Stuktur organisasi, Tenaga kerja: jumlah tenaga kerja yang bekerja, upah tenaga kerja, jam kerja, pembagian kerja/tugas, Letak lokasi usaha atau bangunan.

d. Aspek teknis dan produksi: Sumber bahan baku, jumlah bahan baku yang dipakai dalam proses produksi $(\mathrm{Kg})$, jenis bahan baku, Peralatan yang digunakan dalam proses produksi, Proses produksi, Jenis produk yang dijual.

e. Aspek pemasaran: Proses pemasaran, Daerah/wilayah pemasaran produk. Target pasar.

\section{Analisis keuntungan, komponen-komponen} yang dikaji seperti:

a. Produksi, yaitu jumlah produk yang dihasilkan oleh rumah kopi Monocafe dalam satu hari (cangkir atau porsi/hari).

b. Harga, harga jual produk rumah kopi Monocafe dalam porsi (Rp/cangkir atau porsi).

c. Bahan baku, jumlah bahan baku yang dipakai dalam proses produksi per bulan $(\mathrm{Kg} / \mathrm{bln})$.

d. Bahan penolong, jumlah bahan penolong yang digunakan untuk membantu proses produksi.

e. Biaya produksi, besarnya biaya yang dikeluarkan dalam pengolahan produk yang dihasilkan dalam satu bulan. Variabel ini diukur dalam satuan rupiah per bulan (Rp/bln), yang terdiri atas:

1) Biaya tetap : Biaya penyusutan alat $(\mathrm{Rp})$

2) Biaya variable: Biaya bahan baku (Rp), Biaya penolong (Rp), Biaya listrik, tenaga kerja, wifi (Rp).

\section{Metode Analisis Data}

a. Untuk mengetahui profil usaha rumah kopi Monocafe Manado, dianalisa secara deskriptif dan dengan menggunakan tabel.

b. Untuk mengetahui besarnya keuntungan yang diperoleh dari usaha yang dilakukan dengan rumus adalah :

$$
\pi=\mathbf{T R}-\mathbf{T C}
$$

Keuntungan $(\pi)=$ Total Penerimaan (TR) - Total Biaya (TC)

c. Untuk mengetahui besarnya nilai penyusutan pada setiap barang atau peralatan yang dipakai rumus :

$$
D=\frac{P-S}{n}
$$


Dimana :

$\mathrm{D}($ Despreciation $)=$ Biaya Penyusutan $(\mathrm{Rp} / \mathrm{thn})$

$\mathrm{P}($ Price $) \quad=$ Harga awal barang $(\mathrm{Rp})$

$\mathrm{S}($ Salvage Value $)=$ Harga akhir barang $(\mathrm{Rp})$

$\mathrm{n}($ Life Time $)=$ Perkiraan umur ekonomis (tahun)

\section{HASIL DAN PEMBAHASAN}

Deskripsi Usaha Rumah Kopi Monocafe

Rumah kopi merupakan salah satu jenis usaha industri kecil yang bergerak di bidang pengolahan makanan dan minuman. Dalam proses produksi, usaha ini menggunakan kopi Robusta dan Arabica sebagai bahan baku. Rumah kopi yang merupakan usaha kuliner yang juga sangat populer di semua kalangan di Kota Manado sehinggah membuat pemilik rumah kopi Monocafe ingin juga membuka atau menjalankan usaha rumah kopi. Usaha rumah kopi dengan nama Monocafe ini mulai berdiri pada September 2016 oleh saudara Gerryl Besouw sebagai pemilik. Saudara Gerryl Besouw berumur 31 tahun merupakan lulusan sarjana dari salah satu Universitas di Kota Manado. Saudara Gerryl Besouw yang merupakan pemilik rumah kopi Monocafe, Dia juga merupakan ketua Paskibraka Kota Manado dan Ketua Nyong dan Noni Manado.

Rumah kopi Monocafe mulai beroperasi dari pagi pukul 09.00 hingga malam pukul 00.00 WITA, rumah kopi ini berlokasi di Lorong Pondol Jalan Boulevard Kecamatan Wenang Selatan Kota Manado. Bangunan yang dipakai untuk usaha rumah kopi Monocafe merupakan bangunan milik sendiri dari pemilik usaha. Pada rumah kopi Monocafe ada beragam menu yang ditawarkan atau dijual, ada menu minuman dan juga menu makanan. Alasan mengapa pemilik rumah kopi Monocafe mendirikan usaha rumah kopi karena kalau melihat peluang usaha, usaha rumah kopi memiliki peluang yang sangat bagus dikarenakan kebanyakan orang lebih memilih rumah kopi sebagai tempat untuk berkumpul dan bersantai.

\section{Modal}

\section{Aspek Keuangan}

Modal pada usaha rumah kopi Monocafe merupakan modal dari pemilik dari rumah kopi sendiri dan tidak mendapat bantuan dari pihak lain. Dari modal yang sudah ada pemilik rumah kopi Monocafe menggunakannya untuk pembelian perlengkapan yang dibutuhkan, dekorasi tempat usaha, peralatan, dan juga bahan yang akan digunakan dalam proses produksi dalam menjalankan usaha ini. Modal yang dipakai cukup besar yaitu sekitar 50 juta rupiah. Dana yang sudah ada seluruhnya dimanfaatkan untuk menjalankan usaha rumah kopi ini.

\section{Jumlah Biaya Dalam Pengadaan Bahan Baku}

Biaya yang digunakan dalam pengadaan bahan baku dalam hal ini adalah bahan baku kopi dalam satu bulan pada usaha Rumah Kopi Monocafe adalah sebesar Rp 360.000,- ini berasal dari harga per kilonya kopi adalah $\mathrm{Rp} 60.000$,- dikali dengan jumlah kopi yang dibeli dalam satu bulan adalah $6 \mathrm{~kg}$.

\section{Aspek Manajemen}

\section{Struktur Organisasi}

Usaha rumah kopi ini merupakan usaha milik sendiri atau pribadi dari pemilik usaha, Jadi di dalam usaha ini mempunyai struktur organisasi yang sederhana karena pemilik selaku yang mempunyai usaha, ia juga merangkum menjadi bendahara dan juga sekretaris, jadi dalam hal ini pemilik mempunyai peran penuh dalam menjalankan usahanya tersebut.

\section{Tenaga Kerja}

Tenaga kerja yang digunakan dalam usaha Rumah Kopi Monocafe adalah berjumlah 6 orang dengan pembagian tugas 4 orang dibagian produksi dan 2 orang lainnya bertugas pada pelayanannya, dengan jam kerja adalah 8 jam kerja setiap hari dengan sistem kerja bergantian atau shift, jam kerja pertama mulai dari 09.00-17.00 dan jam kerja kedua mulai dari 16.00-00.00 WITA.

\section{Letak Lokasi Usaha}

Letak lokasi usaha Rumah Kopi Monocafe berada di Lorong Pondol Jalan Bouleverd Kecamatan Wenang Selatan Kota Manado.

\section{Aspek Teknis dan Produksi}

\section{Bahan Baku}

Sumber bahan baku kopi di dapat dari sahabat pemilik rumah kopi sebagai penyalur. Bahan baku yang digunakan dalam proses produksi satu bulan adalah $6 \mathrm{Kg}$ kopi, dimana terdiri dari $5 \mathrm{Kg}$ kopi Robusta dan $1 \mathrm{Kg}$ kopi Arabika.

\section{Peralatan Yang Digunakan Dalam Proses Produksi}

Dalam proses produksi pada usaha Rumah Kopi Monocafe terdapat peralatan yang digunakan dan bisa dilihat pada Tabel 1 .

\begin{tabular}{lll}
\multicolumn{2}{l}{ Tabel 1. Peralatan Dalam Proses Produksi Usaha Rumah Kopi Monocafe } \\
\hline No & Minuman & Makanan \\
\hline 1 & Rockpresso & Kompor \\
2 & V60 & Wajan \\
3 & Moccapot & Telenan \\
4 & Teko & Spatula \\
5 & Grinder & Pisau \\
6 & Kompor & Baskom \\
7 & Panci & Serok \\
8 & Saringan & Blender \\
\hline \multicolumn{2}{l}{ Sumber : Diolah Dari Data Primer, 2019. }
\end{tabular}




\section{Proses Produksi}

Pada usaha Rumah Kopi Monocafe banyak menu yang disediakan rumah kopi untuk para konsumen atau pembeli ada minuman maupun makanan, untuk itu proses produksi untuk semua produk yang ada di rumah kopi ini sangat banyak menghitung produk yang dijual juga sangat banyak. Tetapi kalau kita melihat pada proses produksi, semua bahan yang akan diolah atau diproduksi semua akan melewati beberapa tahap. Bahan baku misalnya kopi pada minuman akan diolah menggunakan perlatan yang ada sehinggah menghasilkan produk yang dipesan oleh pembeli atau konsumen, begitu juga pada produk makanan bahan bakunya akan diolah dengan peralatan yang tersedia dan menghasilkan produk yang sesuai dengan pesanan konsumen.

\section{Jenis Produk Yang Dijual di Rumah Kopi Monocafe}

Produk yang dijual pada rumah kopi ini sangatlah beragam baik itu minuman maupun dengan makanan, jenis produk yang dijual bisa dilihat pada Tabel 2.

Tabel 2. Jenis Produk Yang Dijual di Rumah Kopi Monocafe.

\begin{tabular}{lll}
\hline No & Minuman & Makanan \\
\hline 1 & Kopi hitam & Nasi goreng mono \\
2 & Kopi susu & Mono sandwicth \\
3 & Espresso & Mie goreng + telur \\
4 & Café latte & Mie kuah + telur \\
5 & Cappucino & Mie goreng double + telur \\
6 & Americano & Mie kuah double + telur \\
7 & Moccacino & Chicken wings \\
8 & Vietnam drip & French fries \\
9 & Regular tea & Roti bakar \\
10 & Strawberry tea & Pisang goroho tipis \\
11 & Lychee tea & Pisang gorohobiasa \\
12 & Lemon tea & Pisang gorohogulamerah \\
13 & Teh Tarik & Mono sampler \\
14 & Fanta susu & Nasi putih \\
15 & Choco latte & Telurdadar \\
16 & Milkshake & Nasi dadarsosis \\
17 & Milo volcano & \\
18 & Milo latte & \\
19 & Mineral water & \\
\hline Sumber $:$ Diolah Dari Data Primer, 2018.
\end{tabular}

\section{Pemasaran \\ Aspek Pemasaran}

Pemasaran adalah suatu proses manajerial yang membuat individu atau kelompok mendapatkan apa yang mereka butuhkan dan inginkan dengan menciptakan, menawarkan, dan mempertukarkan produk yang bernilai kepada pihak lain atau segala kegiatan yang menyangkut penyampaian produk atau jasa mulai dari produsen sampai konsumen (Oskar dkk,2010). Pemasaran rumah kopi Monocafe dapat dilihat pada Gambar 1.

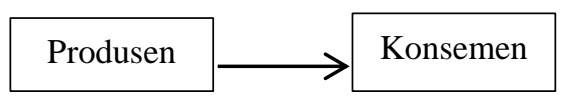

Gambar 1. Saluran pemasaran usaha rumah kopi

\section{Daerah atau Lokasi Pemasaran Produk}

Dalam hal ini lokasi pemsaran produk Rumah Kopi Monocafe terdapat di Lorong Pondol Kecamatan Wenang Selatan Kota Manado.

\section{Target Pasar}

Rumah Kopi Monocafe menetapkan kepada semua kalangan mulai dari orang dewasa sampai anak-anak dapat menikmati semua produk yang ditawarkan oleh Rumah Kopi Monocafe.

\section{Analisis Keuntungan}

\section{Produksi}

Jumlah dan nilai produksi pengolahan di Rumah Kopi Monocafe dapat dilihat pada Tabel 3.

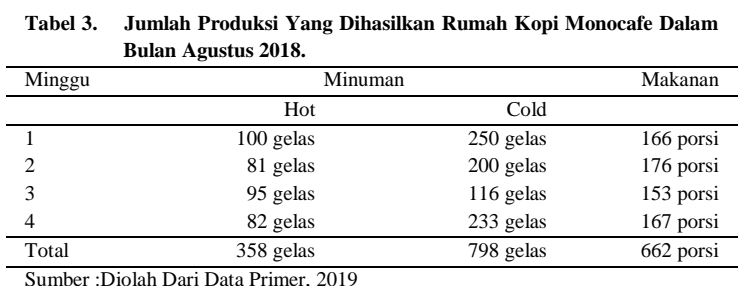

\section{Harga}

Pada Rumah Kopi Monocafe mempunyai harga jual produk yang dapat dilihat pada Tabel 4 .

\begin{tabular}{|c|c|c|c|c|c|}
\hline No & Minuman & Hot (Rp) & Cold (Rp) & Makanan & (Rp) \\
\hline 1 & Kopi hitam & 7.000 & 10.000 & Nasi goreng mono & 19.000 \\
\hline 2 & Kopi susu & 8.000 & 12.000 & Nasi kuning pondol & 13.000 \\
\hline 3 & Espresso & 10.000 & & Mono sandwitch & 19.000 \\
\hline 4 & Café latte & 17.000 & 19.000 & Mie goreng + telur & 13.000 \\
\hline 5 & Cappucino & 17.000 & 19.000 & $\begin{array}{l}\text { Mie goreng double } \\
+ \text { telur }\end{array}$ & 18.000 \\
\hline 6 & Americano & 12.000 & 15.000 & Mie kuah + telur & 13.000 \\
\hline 7 & Moccacino & 17.000 & 19.000 & $\begin{array}{l}\text { Mie kuah double }+ \\
\text { telur }\end{array}$ & 18.000 \\
\hline 8 & Vietnam drip & 15.000 & 18.000 & Chicken wings & 17.000 \\
\hline 9 & Regular tea & 10.000 & & French fries & 15.000 \\
\hline 10 & $\begin{array}{l}\text { Strawberry } \\
\text { tea }\end{array}$ & 15.000 & 12.000 & Roti bakar & 13.000 \\
\hline 11 & Lychee tea & 15.000 & 12.000 & Pisang goroho tipis & 12.000 \\
\hline 12 & Lemon tea & 12.000 & 15.000 & $\begin{array}{l}\text { Pisang goroho } \\
\text { biasa }\end{array}$ & 12.000 \\
\hline 13 & Teh Tarik & 12.000 & 15.000 & $\begin{array}{l}\text { Pisang goroho gula } \\
\text { merah }\end{array}$ & 15.000 \\
\hline 14 & Fanta susu & & 12.000 & Mono sampler & 25.000 \\
\hline 15 & Chocolatte & 17.000 & 19.000 & Nasi putih & 5.000 \\
\hline 16 & Milkshake & & 19.000 & Telur dadar & 5.000 \\
\hline 17 & Milo volcano & & 15.000 & Nasi dadar sosis & 13.000 \\
\hline 18 & Milo latte & & 19.000 & & \\
\hline 19 & $\begin{array}{l}\text { Mineral } \\
\text { water }\end{array}$ & & 5.000 & & \\
\hline
\end{tabular}




\section{Bahan Penolong}

Adapun bahan penolong yang digunakan dalam proses produksi pada Rumah Kopi Monocafe seperti yang dapat dilihat pada Tabel 5 .

\begin{tabular}{|c|c|c|c|c|}
\hline No & Bahan penolong & Pemakaian sebulan & $\begin{array}{l}\text { Harga satuan } \\
\text { (Rp) }\end{array}$ & $\begin{array}{c}\text { Total } \\
\text { (Rp/bulan) }\end{array}$ \\
\hline 1 & Susu kental manis & 40 kaleng & 8.000 & 320.000 \\
\hline 2 & Gula pasir & $5 \mathrm{Kg}$ & 13.000 & 65.000 \\
\hline 3 & Sedotan & 1 pack & 30.000 & 30.000 \\
\hline 4 & Gas & 8 gas & 20.000 & 160.000 \\
\hline 5 & Bawang & $8 \mathrm{Kg}$ & 15.000 & 120.000 \\
\hline 6 & Aqua gallon & 31 galon & 5.000 & 155.000 \\
\hline 7 & Garam & 1 bungkus & 5.000 & 5.000 \\
\hline 8 & Batangbawang & 4 bal & 15.000 & 60.000 \\
\hline 9 & Rica & $4 \mathrm{Kg}$ & 15.000 & 60.000 \\
\hline 10 & Tomat & $2 \mathrm{Kg}$ & 15.000 & 30.000 \\
\hline 11 & Minyak goring & 5 liter & 10.500 & 52.500 \\
\hline 12 & Telur & 40 butir & 2.000 & 80.000 \\
\hline 13 & Roti tawar & 2 bungkus & 10.500 & 21.000 \\
\hline 14 & Mie instan Goreng & 40 bungkus & 3.000 & 120.000 \\
\hline 15 & Mie instan kuah & 40 bungkus & 2.500 & 100.000 \\
\hline 16 & Kentang & $1 \mathrm{Kg}$ & 18.000 & 18.000 \\
\hline 17 & Pisang goroho & 12 sisir & 7.000 & 84.000 \\
\hline 18 & Beras & $15 \mathrm{Kg}$ & 12.000 & 180.000 \\
\hline 19 & Fanta & 4 botol & 11.000 & 44.000 \\
\hline 20 & Milo & 800 gram & & 75.000 \\
\hline 21 & Air mineral & 2 karton & 4.000 & 192.000 \\
\hline 22 & Kecap manis & $600 \mathrm{ml}$ & & 26.500 \\
\hline \multirow[t]{2}{*}{23} & Vetsin & $150 \mathrm{~g}$ & 5.000 & 5.000 \\
\hline & Total & & & 2.003 .000 \\
\hline
\end{tabular}

\section{Biaya Produksi}

Biaya produksi terdiri dari biaya tetap dan biaya variable yang digunakan pada rumah kopi Monocafe. Adapun data yang dianalisis yaitu biaya produksi pada bulan Agustus, terdapat pada ulsan berikut.

A. Biaya Tetap

Dalam usaha rumah kopi Monocafe yang termasuk dalam biaya tetap adalah biaya penyusutan alat. Biaya penyusutan alat dapat dilihat pada Tabel 6 .

Tabel 6. Biaya Penyusutan Alat Rumah Kopi Monocafe.

\begin{tabular}{llrrrrr}
\hline No & Jenis alat & $\begin{array}{c}\text { Jumlah } \\
\text { (unit) }\end{array}$ & $\begin{array}{r}\text { Harga beli } \\
\text { (Rp) }\end{array}$ & $\begin{array}{c}\text { Umur } \\
\text { ekonomis } \\
\text { (bulan) }\end{array}$ & $\begin{array}{c}\text { Nilai sisa } \\
\text { (Rp) }\end{array}$ & $\begin{array}{c}\text { Nilai } \\
\text { penyusutan } \\
\text { (Rp) }\end{array}$ \\
\hline 1 & Rockpresso & 1 & 2.500 .000 & 48 & 1.250 .000 & 24.042 \\
2 & V60 & 1 & 6.000 & 12 & 5.000 & 84 \\
3 & Moccapot & 1 & 200.000 & 48 & 100.000 & 2.083 \\
4 & Grinder & 1 & 1.500 .000 & 48 & 750.000 & 15.625 \\
5 & Teko & 1 & 120.000 & 24 & 80.000 & 1.666 \\
6 & Kompor & 2 & 800.000 & 36 & 400.000 & 11.111 \\
7 & Baskom & 4 & 60.000 & 24 & 35.000 & 1.042 \\
8 & Serok & 1 & 37.000 & 36 & 18.000 & 528 \\
9 & Blender & 1 & 290.000 & 36 & 145.000 & 4.028 \\
10 & Panggangan & 1 & 166.000 & 36 & 85.000 & 2.250 \\
& roti & & & & & \\
11 & Panci & 4 & 500.000 & 48 & 250.000 & 5.208 \\
12 & Kuali & 2 & 300.000 & 48 & 150.000 & 3.125 \\
13 & Telenan & 2 & 100.000 & 12 & 50.000 & 4.167 \\
14 & Spatula & 2 & 90.000 & 12 & 45.000 & 3.750 \\
15 & Pisau & 2 & 100.000 & 24 & 60.000 & 1.667 \\
& Jumlah & & 6.769 .000 & & & 82.376 \\
\hline Sula & & & & &
\end{tabular}

\section{Biaya Variabel}

Biaya variabel pada penelitian ini adalah biaya bahan baku, biaya bahan penolong, dan biaya listrik, tenaga kerja, wifi.

A. Biaya bahan baku

Usaha rumah kopi Monocafe memiliki bahan baku yang terdiri dari bahan baku utama yaitu kopi. Sesuai dengan pengambilan data selama bulan Agustus 2018, dibutuhkan bahan baku kopi sebanyak $6 \mathrm{Kg}$ per bulan dengan biaya dalam pembelian bahan baku sebesar Rp.360.000,- dengan harga per kilonya sebesar Rp.60.000,-

B. Biaya bahan penolong

Bahan penolong lansung merupakan bahan yang digunakan dalam pencampuran pada proses produksi. Pada usaha rumah kopi Monocafe terdapat bahan penolong yang bisa dilihat pada Tabel 5. Pada tabel tersebut biaya yang dikeluarkan untuk pemakaian bahan penolong dalam satu bulan produksi sebesar Rp.2.003.000,-

C. Biaya tenaga kerja

Berdasarkan penelitian, penggunaan tenaga kerja pada usaha rumah kopi Monocafe ada 6 orang. Tenaga kerja diupah sebesar Rp.1.900.000,-/orang. Jadi biaya yang dikeluarkan untuk upah tenaga kerjadalam satu bulan adalah sebesar Rp.11.400.000,-

D. Biaya listrik

Adapun biaya pemakaian listrik untuk usaha rumah kopi Monocafe dalam bulan Agustus 2018 sebesar Rp.1.500.000,-.

E. Biaya wifi

Pada usaha rumah kopi Monocafe terdapat wifi yang dipakai, untuk biaya wifi dalam satu bulan biaya yang dikeluarkan sebesar Rp.750.000.-.

\section{Biaya Total}

Total biaya produksi dari usaha rumah kopi Monocafe merupakan penjumlahan biaya tetap dan biaya variabel yang meliputi biaya penyusutan alat, listrik, bahan baku, tenaga kerja, bahan penolong dan biaya wifi. Pada usaha rumah kopi Monocafe ini mempunyai biaya tetap meliputi biaya penyusutan alat sebesar Rp.82.376,-, sedangkan biaya variabel sebesar Rp.16.013.000,-. Sehingga total biaya yang dikeluarkan untuk proses produksi bulan Agustus 2018 yaitu sebesar Rp.16.100.376,-. Untuk lebih jelas dapat dilihat pada Tabel 7. 
Tabel 7. Total Biaya Produksi Usaha Rumah Kopi Monocafe Dalam Bulan Agutsus 2018.

\begin{tabular}{llr}
\hline No & Uraian Biaya & Nilai (Rp) \\
\hline 1. & Biaya tetap & \\
& Biaya penyusutan alat & 82.376 \\
2. & Biaya variable & \\
& Biaya bahan baku & 360.000 \\
& Biaya bahan penolong & 2.003 .000 \\
& Biaya tenaga kerja & 11.400 .000 \\
& Biaya listrik & 1.500 .000 \\
& Biaya wifi & 750.000 \\
\hline & Total biaya & 16.100 .376 \\
\hline
\end{tabular}

Sumber :Diolah Dari Data Primer, 2019.

\section{Penerimaan}

Penerimaan dari penjualan 1.156 gelas pada minuman dan 662 porsi pada makanan yang dihasilkan pada bulan Agustus 2018, diperinci sebagai berikut, jumlah penerimaan dari minuman yang panas sebesar Rp.6.197.000, dan untuk penerimaan dari minuman yang dingin sebesar Rp.6.632.000, jadi untuk total penerimaan dari minuman yaitu sebesar Rp.12.829.000,-. Sedangkan penerimaan dari produk makanan sebesar Rp.9.522.000,-.Sehingga total dari penerimaan dari minuman dan makanan yaitu sebesar Rp.22.351.000,- .

\section{Keuntungan}

Berdasarkan data yang diperoleh maka keuntungan usaha rumah kopi Monocafe dapat dilihat dengan menghitung total penerimaan dari hasil penjualan produk minuman dan makanan dikurangi dengan total biaya yang dikeluarkan

Keuntungan $=$ Total Penerimaan - Total Biaya

$$
\begin{aligned}
& =\text { Rp. } 22.351 .000-R p \cdot 16.100 .376 \\
& =\text { Rp.6.250.624,- }
\end{aligned}
$$

Jadi keuntungan yang diperoleh Usaha Rumah Kopi Monocafe dalam bulan Agustus 2018 adalah sebesar Rp.6.250.624,-

\section{Rasio R/C}

Analisis R/C merupakan perbandingan penerimaan dan biaya produksi yang dalam penelitian ini bertujuan untuk mengetahui berapa besar tingkat keuntungan dari usaha rumah kopi Monocafe.

$$
\mathrm{R} / \mathrm{C}=\frac{22.351 .000}{16.100 .376}=1,40
$$

Hasil dari analisis ini memiliki arti bahwa biaya total yang dikeleuarkan sebesar Rp.16.100.376,- memperoleh hasil penjualan sebesar 1,40 kali lipat sehinggah layak diusahakan.

\section{KESIMPULAN DAN SARAN}

\section{Kesimpulan}

Usaha rumah kopi Monocafe merupakan usaha berskala kecil yang menggunakan kopi sebagai bahan baku utama. Pada usaha ini tidak mendapatkan bantuan modal dari pihak lain, dengan kata lain modal berasal dari pemilik rumah kopi sendiri. Dalam kegiatan produksi tergantung pada jumlah pesanan dari pembeli dan dalam proses produksi dibantu oleh enam orang tenaga kerja yang berasal dari luar keluarga. Pemasaran dilakukan oleh usaha ini yaitu lansung berhadapan dengan pembeli atau konsumen untuk menjual produk yang dihasilkan. Berdasarkan hasil penelitian, banyaknya produksi dalam satu bulan mengasilkan 1.156 gelas pada minuman dan 662 porsi makanan, sehingga memperoleh keuntungan rasio $\mathrm{R} / \mathrm{C}$ yaitu 1,40 artinya usaha mengalami keuntungan dan usaha ini layak dilanjutkan.

\section{Saran}

Berdasarkan hasil penelitian, maka saran yang dapat diberikan dalam kemajuan usaha rumah kopi Monocafe perlunya meningkatkan promosi agar lebih dikenal masyarakat salah satunya dengan membuat iklan berupa brosur ataupun menggunakan sosial media dalam mempromosikan usaha.

\section{DAFTAR PUSTAKA}

Ariadi, Y. B dkk. 2011. Sistem Agribisnis Terintegrasi Hulu-Hilir. Muara Indah Bandung.

Kurniawan, A. 2005. Profil Usaha Pisang Goroho. Jurusan Sosial Ekonomi Pertanian, Fakultas Pertanian Universitas Sam Ratulangi. Manado. 
Mubyarto. 2004. Pengantar Ekonomi Pertanian. LP3ES. Jakarta.

Mulyadi, D. K. 1999. Laporan keuangan perusahaan dagang. Jakarta.

Oskar, R dkk. 2010. Kiat Sukses Mendirikan dan Mengelola UMKM. L Press, Jakarta.

S, Oestreich-Jansen. 2013. Kimia Kopi tentang Produk Alami Komprehensif II: Kimia dan Biologi, hal 1085-1113. Elsevier.

Salim, Julius. 2016. Businness Plan. Universitas Esa Unggul, Jakarta.

Siswoputranto, P.S. 1992. Kopi Internasional dan Indonesia. Kanisius, Yogyakarta.

Soekartawi. 2000. Pengantar Agroindustri. Rajawali Press. Jakarta.
Soekartawi. 2003. Dasar Penyusunan Evaluasi Proyek. Pustaka Sinar Harapan. Jakarta.

Soekartawi. 2003. Teori Ekonomi Produksi. PT Raja Grafindo Persada, Jakarta.

Stanly, E. 2015. Makalah Perbandingan“ Kedai Kopi” Kewirausahaan. Universitas Narotama. Surabaya.

Syarizal, M. 2015. Company Profile. Program Studi Ilmu Komunikasi Fakultas Ilmu Sosial dan Ilmu Politik Universitas Pasudan. Bandung.

Widiyanto D.L. 2012. Jenis kopi kelas dunia. Tersedia pada: http://dahlanlatif widiyanto.wordpress.com/2012/04/22 jenis-kopi-kelas-dunia/. 